\title{
Memory and Forgetting in a Time of Violence: Brian Friel’s Meta-History Plays
}

\author{
Tony Crowley \\ Scripps College, Ca, USA
}

Copyright (c) 2008 by Tony Crowley. This text may be archived and redistributed both in electronic form and in hard copy, provided that the author and journal are properly cited and no fee is charged for access.

\begin{abstract}
In the 1980s, Brian Friel, one of Ireland's most successful twentieth century dramatists, authored two plays - Translations and Making History - which were concerned with major events in colonial history. Given the context in which the plays were written - Northern Ireland was in a state of war at the time - the playwright's choice of topics (the introduction of the National Schools and the Ordnance Survey in the nineteenth century and the failed Gaelic revolt against English rule and the Flight of the Earls in the sixteenth and seventeenth centuries) was both pointed and politically contentious. Yet, the argument of this essay is that rather than presenting versions of the past which conform to the ideological imperatives of a particular political stance, Friel's plays are much more interesting and significant in that they provoke a whole series of questions around the issue of historical representation. One of the most important of those questions is the applicability of the criteria truth and falsity in historical and other modes of interpretation. The essay concludes with a consideration of the politics of memory and forgetting in contemporary Northern Ireland.
\end{abstract}

Key words. Memory, forgetting, history, violence, representation.

Resumen. En la década de los ochenta Brian Friel, uno de los dramaturgos con más éxito del siglo XX, escribió dos obras - Translations y Making History - en torno a acontecimientos determinantes en la historia colonial. Dado el momento en que se escribieron las obras - Irlanda del Norte estaba sumida en estado de guerra - la elección de los temas (introducción de las Escuelas Nacionales y el Servicio Oficial de Cartografía en el siglo XIX y la fallida revuelta gaélica contra el yugo inglés y la Huída de los Condes en los siglos XVI y XVII) fue significativa y políticamente contenciosa. No obstante, el argumento de este ensayo es que más que ofrecer versiones del pasado dictadas por una determinada posición ideológica y política, las obras de Friel resultan mucho interesantes y significativas en tanto que generan una serie de preguntas en torno al tema de la representación. Una de las cuestiones clave es la aplicabilidad de los criterios de verdad y falsedad en la interpretación, histórica o de otro tipo. El ensayo concluye con una consideración de la política de la memoria y el olvido en la Irlanda del Norte contemporánea.

Palabras clave. Memoria, olvido, historia, violencia, representación.

In the 1980s, Brian Friel, one of Ireland's most successful twentieth century dramatists, authored two plays which were concerned with major events in colonial history. Given the context in which the plays were written Northern Ireland was in a state of war at the time - the playwright's choice of topics was both pointed and politically contentious. Translations deals with the impact of the introduction of the National Schools - an English language based education system and the Ordnance Survey - a scheme to map and name the places of the British Empire carried out by the Royal Corps of Engineers - 
upon an Irish-speaking community in a remote part of rural Ireland in $1833 .{ }^{1}$ Making History, set in the period encompassing the Nine Years War (1592-1601) and the Flight of the Earls (1607), concerns an important revolt against colonial rule, a significant defeat for the Irish forces, and a turning point in the fortunes of the native Gaelic culture. ${ }^{2}$

The late 1970s and the 1980s were particularly bloody and bitter years in the war between the forces of Irish Republicanism and the British State and its supporters; during this time the Irish Republican Army came extremely close to killing the British Prime Minister and her Cabinet and the first evidence began to appear - since validated - of collusion between the State and illegal paramilitary forces in political murder. The violence of the period in which both plays were written and performed provided a context in which issues of memory and forgetting were urgent and insistent. Indeed in one sense it is clear that the propensity to engage in violence on all sides was predicated precisely on an appeal to the importance of history. The one thing which seemed to unite all the parties was the need to remember the past; despite their different interpretations of history, the forces of Irish nationalism, pro-British Unionism and even the British cited the past as source, authority, and justification.

Given Friel's decision to take key moments in Ireland's colonial past as the subject of these two dramas, it might be thought that Translations and Making History would conform to the ideological imperatives of one version of history and offer, say, an exploration of the confrontation between the native Irish and the colonial powers wielded by the British Empire (in the nineteenth century) and the English State (in the early seventeenth century). Yet although it is possible to read the plays in this way - one of the charges levelled against them is indeed that they are instances of nationalist drama - such a reading does not do justice to the complexity of Friel's stagecraft, nor, more importantly, to the

1. Brian Friel, Translations, London: Faber, 1981. All page references in the essay are to this edition.

2. Brian Friel, Making History, London: Faber, 1989. All page references in the essay are to this edition. significance of the political and cultural issues which he invokes. ${ }^{3}$ The concern of this paper therefore will be to look at the questions which Friel's work raises with regard to the matter of memory and forgetting in a period of violence and, towards the end of the essay, to the problem of what should be remembered and what should be forgotten once hostilities cease and, to use the ironic phrase, 'peace breaks out'. Such issues are of course not restricted to Northern Ireland and comparable debates are and have been taking place in many postconflict societies; South Africa and Argentina are two striking examples where, despite the specific differences, there are notable similarities with Northern Ireland. In each of these contexts there is a shared concern to 'deal with the past', yet that phrase itself reveals some of the problems which are involved in any such project in a situation in which bitterness, division and violence were the social norms. 'To deal with' can mean 'to handle effectively', but it also has the sense 'to dispose of' ${ }^{4}$ Can the past be 'dealt with' by disposing of it? What would it mean to handle it 'effectively'?

By dint of the burden placed on history in Northern Ireland, such questions have been and remain significant. Now that the violence has ended, how is the past to be dealt with? Is there an obligation to remember? Is there a duty to commemorate? Does peace depend on forgetting? Can democratic politics function only by misremembering? In one sense such questions have already been decided at the level of the street. One of the remarkable things about the Troubles in Northern Ireland is the way in which events, issues and people were and are recorded in the everyday spaces of people's lives. The Conflict Archive on the

3. For an examination of this charge against Friel's work, see Marilynn Richtarik, Acting Between the Lines: The Field Day Theatre Company and Irish Cultural Politics 1980-1984, Oxford: Clarendon Press, 1994.

4. The OED gives: 'to deal with: to act in regard to, administer, handle, dispose in any way of (a thing); b. to handle effectively; to grapple with; to take successful action in regard to'. It is interesting to note that the verb 'deal' itself has a number of senses based on the concepts of division and sharing, including one which refers to violence - 'to deal someone a blow'. 
Internet, together with the Claremont Colleges Digital Library, hold collections of thousands of images of plaques, murals and memorials (Gardens of Remembrance, statues, monuments) which have appeared throughout the past forty years or so. ${ }^{5}$ Such records were often erected or painted by political or paramilitary organisations, sometimes by local communities, in order to memorialise deaths, to laud heroes, to intimidate and warn, to encourage and rally, to send political messages to the other side and so on. They were, almost universally, designed from a specific perspective, in a hostile and conflictual environment, for particular purposes; many proved ephemeral, some have endured. But if these are local and politically partial representations of history, memory on the street, what happens if the questions posed earlier are taken to a level which encompasses the whole of the divided society? What is it that post-conflict Northern Ireland has to remember, commemorate, forget or misremember in order function as an inclusive democratic society? Though such questions are never addressed directly in Friel's Translations and Making History - Friel is too sophisticated a playwright to engage in didactics - it is clear that these plays do at least implicitly present these issues for our attention. They do so not by presenting specific details of Irish history which must be recalled, but by considering how and why things are remembered and forgotten and by drawing attention to the criteria which apply to representations of the past. In that sense these are not so much history plays as meta-history plays; they are not concerned with presenting a particular view of an historical event - the introduction of the National Schools, the Ordnance Survey, the Nine Years War - as with an examination of the nature of historical representation itself.

Translations centres upon an issue which involves memory and forgetting in colonial and post-colonial Ireland: the loss of the native language. Though this process (including the

5. The Conflict Archive on the Internet (CAIN) site (http://cain.ulst.ac.uk/) is concerned with Conflict and Politics in Northern Ireland 1968 to the Present. My own collection of some 600 images of murals spanning the period 1979-2004 can be found at the Claremont Colleges Digital Library (http://ccdl.libraries.claremont.edu/col/mni/).
Anglicising of place-names) took place over centuries, its pace increased markedly in the nineteenth century. In the 1830s, out of a total population of some eight million, about two million spoke only Irish and understood no English, while another two million were bilingual; thus about half of the population spoke Gaelic and a quarter of the total spoke little or no English. Just eighty years later, in 1911, immediately before independence from British rule, just $13.3 \%$ of the population were recorded as speaking any Gaelic and less than $3 \%$ were Irish monoglots. Over the course of less than a century, Ireland became largely Anglicised and the Irish language almost died as a living communal language; Ireland took its place, along with many other colonies under British rule, in the English-speaking world. ${ }^{6}$

There were many important factors involved in the loss Irish of the language over a long period: the colonial economic and legal systems, industrialisation and urbanisation, the decision by the Catholic Church to use English rather than Irish as its medium, and the extension of the British State into Ireland after the Act of Union in 1800. But Translations focuses on two cultural factors in this process: the introduction of a State-sponsored, English language-based education system for Irish children by means of the National Schools in 1831, and the 'standardising' of Irish placenames through the Ordnance Survey after 1824. The displacement of the Hedge Schools (a remarkably successful native mode of education in the Irish language organised against colonial repression in the eighteenth century) by a State-funded education system is treated with Friel's favoured technique of irony. For example when one of the locals asserts that the State schools, unlike the Hedge Schools, would be free, open year-round and compulsory for children between the ages of six and twelve, 'no matter how smart you are or how much you know', the claim is met with incredulity. The simple but historically ironic retort is : 'Who told you that yarn?... they're

6. For an account of the politics of language in Ireland in this period, see chapters five and six, 'Culture, politics and the language question, 1789-1876' and 'Language and revolution, 1876-1922', in Tony Crowley, Wars of Words: The Politics of Language in Ireland 1537-1922, Oxford: Oxford University Press, 2005. 
not going to take on - law or no law' (Friel, 1981, 22). The play also illustrates the complexity of the nineteenth-century debates surrounding the role, significance and future of the Irish language in Ireland. Not least, of course, the very medium in which the play is written stands as a political comment on the language question in Ireland. For although it seems 'natural' that the all of the characters on stage speak English to each other, that ideological belief is ruptured in Brechtian fashion when it becomes clear that the Irish characters are in fact speaking Gaelic: the text demands an act of cultural imagination which reveals how our familiarity with English as a colonial language has led us to forget the history behind that fact. It comes as something of a surprise then, not to learn that the English soldiers do not speak Irish, but that only a few of the Irish characters speak English - 'on occasion - outside the parish of course and then usually for the purposes of commerce, a use to which [the] tongue seemed particularly suited' (Friel, 1981, 25). ${ }^{7}$ But the confidence with which the native language culture is portrayed here (which serves as an ironic contrast to colonial arrogance about English) is undermined when Maire, a young woman faced with the prospect of emigration, rebels against the Hedge School's use of Gaelic to teach the classical languages, by citing the argument of the most successful leader of nineteenth-century Irish political nationalism, Daniel O'Connell, that 'the old language is a barrier to modern progress'. ${ }^{8}$ 'I don't want Greek. I don't want Latin', she states, 'I want

7. Hugh's comment here is not implausible historically. Christopher Anderson noted in his Brief Sketch of Various Attempts which Have Been Made to Diffuse a Knowledge of the Holy Scriptures through the Medium of the Irish Language (1818), that for the Gaelic speaker English is 'the language of barter, or worldly occupations; taken up solely at the market, laid aside when he returns home, a very confined vocabulary'.

8. O’Connell was a native Gaelic speaker. He nonetheless argued that English was the language of political progress: 'although the Irish language is connected with many recollections that twine around the hearts of Irishmen, yet the superior utility of the English tongue, as the medium of modern communication, is so great, that I can witness without a sigh the gradual disuse of the
English' (Friel, 1981, 25). Though she specifically does not say that she doesn't want Irish, Maire voices the pragmatic linguistic interest of the impoverished colonial subject; she wants English because, as the oldest of eleven children in a fatherless house, she knows that she needs the language in order to be able to emigrate to America.

The issue of historical memory and forgetting in a colonial context is treated in Translations through a critical questioning of the significance of one aspect of the loss of the native language: the Ordnance Survey's attempt to take the existing Gaelic names and to record them by 'standardising' them in English (by transcription, translation or Anglicisation). This is raised specifically in a scene in which the proper naming of a crossroads - called Tobair Vree in Gaelic - is discussed by Yolland, a soldier-cartographer for the colonial project, and Owen, the local translator and 'go-between'. 9 Yolland, the reluctant colonial servant, has misgivings about his part in the process of re-naming and describes it as 'an eviction of sorts'; 'something', he says, 'is being eroded' (Friel, 1981, 43). Owen, the native informant employed by the British, responds:

we call that crossroads Tobair Vree. And why do we call it Tobair Vree? I'll tell you why. Tobair means a well. But what does Vree mean? It's a corruption of Brian - (Gaelic pronunciation). Brian - an erosion of Tobair Bhriain. Because a hundred and fifty years ago there used to be a well there, not at the crossroads, mind you - that would be too simple - but in a field close to the crossroads. And an old man called Brian, whose face was disfigured by an enormous growth, got it into his head that the water in the well was blessed; and every day for seven months he went there and bathed his face in it. But the growth didn't go away; and one morning Brian was found

Irish' (Crowley, Wars of Words, p.102). O'Connell's stance contrasted fundamentally with that of the leaders of Irish cultural nationalism; the split persisted throughout the nineteenth century and up until the achievement of Independence in 1921.

9. Yolland's function, like that of the other soldiers, is to engage in map-making; his specific task combines the roles of toponymer and orthographer. 
drowned in that well. And ever since that crossroads is known as Tobair Vree - even though that well has long since dried up. I know the story because my grandfather told it to me. But ask Doalty - or Maire - or Bridget - even my father - even Manus - why it's called Tobair Vree; and do you think they'll know? I know they don't know. So the question I put to you, Lieutenant is this: What do we do with a name like that? Do we scrap Tobair Vree altogether and call it - what? - The Cross? Crossroads? Or do we keep piety with a man long dead, long forgotten, his name 'eroded' beyond recognition, whose trivial little story nobody in the parish remembers? (Friel, 1981, 44).

Owen's question here is an important one, but the terms in which he poses it are revealing. What should the place be called? How is it to be recorded for memory? Should the 'corrupt' version of the Gaelic name be retained, or should they simply invent an English name for it?

There are familiar positions from which answers to these questions might be articulated. A cultural nationalist, anti-colonial response might be that the native name must be remembered and used since it encapsulates an element of national identity, that is is a crucial concatenation between past and present on which the political future of the nation depends (the link between language and national identity having been reified by the cultural nationalists of the late eighteenth and nineteenth centuries in Ireland and across Europe). A colonial answer, on the other hand, might be that a more functional English name should be used since that is simply more convenient and less 'confusing', a means perhaps of wiping the historical slate clean, effacing a trace of a distinctive past and starting at colonial year zero. But it is interesting that Friel switches the colonial and anti-colonial positions by having the British soldier worry about the erosion of Irish culture while the Irishman argues that the Irish name captures nothing but a quaint story. It may be that by reversing the stances that one might expect from these characters, Friel is suggesting that there is another way of thinking about the name 'Tobair Vree' which doesn't fit into the models offered by colonialism and its nationalist counterpart. Perhaps the argument for the retention of 'Tobair Vree' is not that the name embodies in some way an element of Irish national identity, guaranteeing a seamless link between past and present, nor because it thereby resists linguistic colonialism, but simply because this is its historical name. The name itself, to adopt a phrase of Saussure, is an example of 'motivated arbitrariness'; it is arbitrary in the sense that there is no good reason why this place is called 'Tobair Vree' (it is a corruption of the original Gaelic phrase for 'Brian's well', but it could just as well have been called 'the cursed well' or 'the drowned man's well'), but it is motivated in that this is the story which attaches to it and which is used to explain its origin. ${ }^{10}$ The story itself may or may not be true (the genetic fallacy is indeed a fallacy), but that isn't the point. Nor is the important thing to 'keep piety' with a man long dead and thus to adopt a sacral attitude to the past. So when Owen asks 'what the hell does Vree mean?' (Friel, 1981, 44), the answer is that in itself it means nothing - it is simply part of a name. And the name itself, 'Tobair Vree', 'means' nothing either, except within the discourses of nationalism and colonialism, though it does provide access to an aspect of local history. Perhaps this is why Yolland insists that 'Tobair Vree' be recorded in the name-book. Not because 'Tobair Vree' is the 'right' or 'wrong' name for this place, either from a colonial or anti-colonial perspective, but because this is just its name - a name which has been shaped and 'eroded' over time by the linguistic usage of the people living in this place. It may be Yolland's attempt to escape the strictures of nationalism (to which he is not allowed to belong) and colonialism (to which he does not want to belong).

Naming forms an important aesthetic and political motif throughout Translations, and Owen insists on being called by his proper name after having been called 'Roland' by the

10. Saussure uses the idea of the 'motivation' of a sign in a technical and different sense to the way in which I am using it here. For Saussure, although 'the basic condition of the linguistic sign' is its absolute arbitrariness, he also holds that 'the sign may be motivated to a certain extent' (italics in original). What he means by this is that although the French term 'vingt' (twenty) for example is absolutely arbitrary, ‘dix-neuf' ('nineteen') is 'motivated' and thus only relatively arbitrary because it is formed by combination of the terms 'dix' and 'neuf'. For Saussure's discussion of 'absolute arbitrariness and relative arbitrariness', see Ferdinand de Saussure, Course in General Linguistics, trans. and annotated by Roy Harris, London: Duckworth, 130-132. 
British soldiers in the early part of the play. After angrily, and then laughingly, revealing the mistake to the embarrassed Yolland, both men drink and celebrate their name-giving activities:

Owen: A christening!

Yolland: A baptism!

Owen: A hundred christenings!

Yolland: A thousand baptisms! Welcome to Eden!

Owen: Eden's right! We name a thing and - bang! it leaps into existence!

Yolland: Each name a perfect equation with its roots.

Owen: A perfect congruence with its reality (Friel, 1981, 45).

This is an interesting comment on language and evidently refers to Biblical accounts of naming - baptism, Christening, and the primordial scene of naming - Eden. But it raises questions about the potential of the act of naming, a power crucially related to remembering and forgetting. For example, the dialogue between the two characters reveals a fundamental misunderstanding of the Creation story in Genesis; in that myth, it is God rather than human beings who has the ability to use language to create ('And God said Let there be light: and there was light', Genesis, 1.3). ${ }^{11}$ Human beings have the secondary role of giving names to things which had already been created: 'and whatsoever Adam called every living creature, that was the name thereof' (Genesis, 1.19). Thus the Biblical story presents a version of nominalism rather than realism - each name is not 'a perfect equation with its roots', nor is the relationship between name and things 'a perfect congruence with reality'. The myth does not assert either a logical or a natural link between a name and its roots, nor does it suggest that there is a fit between language and reality. Rather, it says that whatever human beings call things simply is their name; it is an arbitrary (in the technical Saussurean sense of the term) and therefore historical fact. $^{12}$

11. The Bible. Authorized King James Version, Oxford: Oxford University Press, 1997. All references are to this edition.

12. Saussure's own account is of course antinominalist and his work in part grows out of a methodological rejection of the interest in the origin of language within the nineteenth century science of language.
Throughout Translations Friel explores a number of ideas about the relation of language to reality and its importance for memory. At one point, for example, Hugh, the drunken schoolmaster of the Hedge School, tells Yolland that the members of the Irish-speaking rural community of Baile Beag 'like to think we endure around truths immemorially posited' (Friel, 1981, 42). This appears to suggest that such truths, the meanings that this culture has found to be significant, posited at a time which lies beyond remembrance, have been transmitted to the present in the idealist, ahistorical manner which used to characterise what was meant by the term 'tradition'. Yet this seems incompatible with Hugh's assertion later that words - the medium of transmission of such 'truths' - are nothing more than 'signals, counters. They are not immortal. And it can happen that a civilisation can be imprisoned in a linguistic contour which no longer matches the landscape of... fact' (Friel, 1981, 42). In this case, the claim appears to be that a 'civilisation' may need to change its language in order to escape the constraints imposed by that language, a point reinforced later when he proposes that 'it is not the literal past, the "facts" of history, that shape us, but images of the past embodied in language' (Friel, 1981, 66). This leads him to assert that 'we must never cease renewing those images; because once we do we fossilise' and thus, in relation to the colonial process of re-naming, that 'we must learn those new names... We must learn where we live. We must learn to make them our own. We must make them our new home' (Friel, 1981, 66). The problem with Hugh's account of the importance of language, however, which makes it curiously contradictory, is that at one and the same time it seems to cede tremendous power to language and to count it as simply incidental. For if it is not the facts of history which shape human lives, but linguistic representations of the past, then how can it also be the case that the language of the community can be so casually cast aside and the new language adopted? What of the 'truths' which were passed on so seamlessly from the past? Can the 'truths immemorially posited' around which the Baile Beag community endures be transmitted unproblematically in the new language? And who is it precisely who has the authority to decide that the language of a community no longer matches its own reality? 
Part of the difficulty with Hugh's account of representation is that he wants to draw a strict demarcation between the 'facts of history' and 'images of the past embodied in language' (in words, phrases, narratives) - as though representations of the past were not also facts of history. But Hugh's simplistic dichotomy with regard to the forces that shape human reality is challenged towards the end of the play by his son Owen when he asserts that there is 'one single, unalterable "fact"': if Yolland, the missing soldier, is not found, the local inhabitants of Baile Beag are going to be evicted (Friel, 1981, 66). The mysterious disappearance of the colonial cartographer, and the subsequent threats of retribution against the locals unless he is found, force Owen to give up his role as 'go-between' and to revise his opinion about his part in the British re-naming project. Calling the official name-book 'a mistake - my mistake - nothing to do with us', he responds to Hugh's assertion that the locals should learn where they live in relation to the colonial names, to make their 'new home' amongst them, by retorting: 'I know where I live' (Friel, 1981, 66). This is not a statement of geographical or linguistic knowledge but an instance, to adapt Frederic Jameson's phrase, of cognitive mapping - in this case a political recognition of his social position brought about by the threat of colonial force. ${ }^{13}$ Owen, subject to threats of violence, gains knowledge of his own place; perhaps another way of putting this would be that he simply comes to understand where he, his family and his neighbours live historically.

Translations ends with a number of acts of remembering and forgetting. Hugh, as noted earlier, declares that 'to remember everything is a form of madness', but nonetheless recounts taking part in the important 1798 Rebellion against British rule in Ireland, a rebellion annually remembered and formally commemorated by the Irish Republican movement as its founding moment. ${ }^{14}$

13. Jameson uses the phrase in 'Postmodernism, or, the Cultural Logic of Late Capitalism', New Left Review, I/146, 1984, 92.

14. Each June Irish Republicans gather at Bodenstown cemetery at the grave of Theobald Wolfe Tone, a leader of the 1798 Rebellion of the United Irishmen against British rule in Ireland. The practice of gathering at Bodenstown for this commemoration was started in the late nineteenth century.
Gloriously nostalgic, Hugh tells how he and his colleague Jimmy Jack marched twenty three miles in a day before they stopped at a pub, became homesick, and, he admits bathetically, walked all the way back again. Maire, the young Irish woman who said she wanted the English language and who later fell in love with the soldier Yolland, wanders on stage and says 'I'm back again. I set out for somewhere but I couldn't remember where. So I came back here' (Friel, 1981, 6). And in the final speech of the play, Hugh attempts to recite an ancient myth which he claims to know 'backways', but which he forgets. In a play which concerns itself so much with the power of language to represent the past, it is telling that the final words are those of a story that cannot be remembered, that has to be started again, and which is left unfinished.

Translations raises issues of memory and forgetfulness in relation to Ireland's colonial past, but it is in Friel's later play Making History that such questions are considered directly. Set against the decisive defeat by English colonial forces of the Gaelic chieftains led by Hugh O'Neill at the end of the sixteenth and early seventeenth centuries, a loss which is often taken to mark the beginning of the end of the Gaelic cultural order, Making History lays out a number of central issues with regard to the representation of history. These take the form of a debate between Hugh O'Neill, considered to be the first Gaelic chieftain to unite the various clans of Ireland against the colonists, and his historiographer, Archbishop Peter Lombard. $^{15}$ Essentially an argument about the nature, function and purpose of history-writing, their dialogue also serves as a commentary on recent debates in Irish historiography. Like Translations, therefore, Making History takes as its theme a key event in the Irish colonial past but presents it in such a manner as to pose open questions about

15. Peter Lombard, an Irishman, was educated at Westminster School and Oxford University before leaving for Louvain where he became a Doctor of Divinity and was ordained a Catholic priest; he moved to Rome in the 1590 s and was created Archbishop of Armagh in 1601. The repression of Catholicism in the period meant that after his early years in Waterford, he did not set foot in Ireland again. In 1600 he composed De Regno Hiberniae Sanctorum Insula Commentarius, first published at the Counter-Reformation centre of Louvain in 1632. 
memory and forgetting which resonate in Ireland today.

When it is first mentioned that Lombard is writing a history, O'Neill's response is to become 'suddenly alert' and to reply defensively that 'we have our own annalist' (Friel, 1989, 5). The annalists played an important function in Gaelic culture as professional bards whose responsibility was to record history in highly conventional form. O’Neill's sensitivity about Lombard's history therefore suggests that he senses that this is not to be a traditional account, but one which would be less formulaic and have a specific political purpose. $^{16}$ This explains O'Neill's quizzing of the Archbishop about the process of writing the history. When Lombard says that after checking events and dates he will 'try to arrange the material into a shape', O’Neill wants to know if he will then interpret the material; 'not interpret, Hugh', the Archbishop counters, 'just describe'. Not satisfied, O’Neill presses: will the history then be 'without comment?'; it will be told 'as accurately as I can', the Archbishop responds. Evidently O’Neill finds Lombard's answers disturbing. He twice asks the significant question, 'but you'll tell the truth?', to which Lombard replies:

If you're asking me will my story be as accurate as possible - of course it will. But are truth and falsity the proper criteria? I don't know. Maybe when the time comes my first responsibility will be to tell the best possible narrative. Isn't that what history is, a kind of story-telling? (Friel, 1989, 8).

Despite asserting that he is unsure about the historian's function and method, Lombard nonetheless explains that his way of working is that of 'imposing a pattern on events that were mostly casual and haphazard and shaping them into a narrative that is logical and interesting' (Friel, 1989, 8). Returning to the question of 'truth', the Archbishop declares that he is 'not sure that "truth" is a primary ingredient'... It may be, he continues, that when the time comes, 'imagination will be as important as information’ (Friel, 1989, 8-9).

16. Lombard's De Regno was one of a number of Counter-Reformation texts which attempted to foster a new religious and political consciousness in Ireland through a revisionist approach to the themes and concerns of traditional Irish historiography. See Nicholas Canny, 'The Formation of the Irish Mind: Religion, Politics and Gaelic Irish Literature 15801750', Past and Present, 95 (1982), 91-116.
Hayden White, quoting Croce, asserted that 'where there is no narrative, there is no history' and we are by now familiar with the idea that history is narrativised - subject to the formal conventions of story-telling. ${ }^{17}$ Lombard proposes such a view when he defends his approach to the writing of O'Neill's history by arguing that 'I don't believe that a period of history - a given space of time - my life - your life - that it contains within it one "true" interpretation just waiting to be mined. But I do believe that it may contain within it several possible narratives'. Thus, he continues, 'the life of Hugh O'Neill can be told in many different ways' which are 'determined by the needs and the demands and the expectations of different people and different eras. What do they want to hear? How do they want it told?' With regard to his own position this means that as historian, he is 'not altogether my own man... To an extent I simply fulfil the needs, satisfy the expectations' (Friel, 1989, 15-16). The Archbishop's argument here is canny, but its significance lies in the fact that Friel is using it to provoke a set of important questions for historiography and for the remembrance of the past. Thus while it is clearly the case that periods of history don't contain just one 'true' interpretation waiting to be discovered, is it any more true that they 'contain' several possible narratives? What does this mean for the political agency of the historian? And what type of political model of interpretation is being invoked by the Archbishop? Moreover, are the narratives of history 'determined' by the 'needs', 'demands' and 'expectations' of the audience? If they are, who decides exactly what the historical audience is, what it needs, demands and expects, and how it wants its narrative to be delivered?

Lombard's thesis on historiography is developed towards the end of the play in a furious argument between the Archbishop and O’Neill, by this time a pathetic, defeated exile. Lombard declares:

17. Hayden White, The Content of the Form: Narrative Discourse and Historical Representation. Baltimore: The Johns Hopkins University Press, 1987, 5. For a useful discussion of the impact of modern critical and cultural theory on historiography, see Elizabeth A. Clark, History, Theory, Text: Historians and the Linguistic Turn, Cambridge, Mass., Harvard University Press, 2004. 
People think they just want to know the 'facts'; they think they believe in some sort of empirical truth, but what they really want is a story. And that's what this will be: the events of your life categorized and classified and structured as you would structure any story... That's what I'm doing with all this stuff - offering a cohesion to that random catalogue of deliberate achievement and sheer accident that constitutes your life. And that cohesion will be a narrative that people will read and be satisfied by (Friel, 1989, 66-7).

Somewhat riskily for an Archbishop, he compares his own method with that of the Evangelists who took the 'haphazard events Christ's life and shaped them into a story' - a story, he notes, which we call 'gospel' (as in 'the Gospel truth'). Lombard's rhetoric is once more persuasive, but it needs to be considered carefully. Is there quite such a rigid demarcation between 'facts' and 'story' as that which Lombard proposes? Are people who believe ('think they believe'?) in 'some sort of empirical truth' (what sort?) simply deluded about what they want? Is categorization, classification and structure not a question of interpretation rather than description? Do stories have to 'cohere' in order to satisfy? Isn't a 'random catalogue' an oxymoron? Again the point here is not that Friel is presenting an accurate version of a debate between O'Neill and Lombard, or a historically faithful record of the Archbishop's words. Rather the Archbishop's speech raises a set of questions which are concerned with the politics of representation - specifically in this case with the issue of how a narrative of the past is shaped to suit its function and its purpose.

Making History ends with Lombard and O'Neill reciting two versions of O'Neill's life. Lombard chooses to use the conventions of Gaelic genealogy to begin his account: 'Son of Feardorcha, son of Conn Bacagh, son of Conn Mor, noblest son of noble lineage, who was fostered and brought up by the high-born nobles of his tribe...' (Friel, 1989, 70). By contrast O'Neill repeats the text of his submission to Elizabeth the First after his defeat which begins with his recognition of English colonial legitimacy: 'By the Queen of England, France and Ireland her most gracious favour created Earl of Tyrone...' (Friel, 1989, 70). As with Translations the ending of this play is inconclusive - neither of the accounts of O'Neill's life is privileged - and we are left as members of the audience with the questions which Lombard posed earlier: which of these accounts do we find satisfying? Which fulfils our needs and demands and expectations? And once those questions are brought up, the crucial issue then remains to be answered: why this one rather than the other?

One specific issue which Lombard raises haunts the play: are truth and falsity the proper criteria to apply to historical representations? One way of thinking about the ending of Making History is that it simply presents two contradictory accounts and suggests how difficult it is to judge between them; that is to say, it draws attention to the complexity of historical interpretation and the problem of truth and falsity. But although it is certainly the case that the play problematizes the interpretation of history, and thus cannily engages with recent debates within Irish historiography, it does so in a way which seeks to challenge and disturb rather than to provide answers. For throughout Making History Friel subtly invokes a provocative motif which brings to the fore the issue of the status and function of truth and falsity as criteria. Early in the play the English Queen's Marshal in Ireland writes to the sovereign regretting that by dint of his sister's marriage to O'Neill, his blood has been 'mingled with so traitorous a stock'; O'Neill's response to this is to call him a 'Staffordshire mongrel' (Friel, 1989, 6). Later O'Neill's wife's sister visits her and brings her seeds with a warning - 'Don't plant the fennel near the dill or the two will crossfertilize' and 'you'll end up with a seed that's neither one thing or the other' (Friel, 1989, 6). And in an episode which represents a personal tragedy for O'Neill, when he is on the run from English forces he is given the news that his wife and new-born have died - 'herself and the baby within two hours - the doctor said something about poisoning of the blood' (Friel, 1989, 53).

One way of interpreting these references to the dangers of mingling and cross-fertilisation is to see them as a fulfilment of the implicit warning in Jimmy Jack's question to Hugh at the end of Translations : 'Do you know the Greek word endogamein? It means to marry within the tribe. And the word exogamein means to marry outside the tribe. And you don't cross those borders casually - both sides get very angry' (Friel, 1981, 68). What are we to make of the fact that in Translations an English soldier and an Irish woman fall in love and tragedy ensues, and in Making History an 
Irish chieftain and the daughter of the Queen's Marshall marry and disaster follows? Is this simply a pessimistic declaration about the impossibility of cross-cultural exchange in a colonial context? Or a coded warning about the dangers of personal contact with 'the other side' in a time of violence such as the period in which the play was written? If this was merely an admonishment to stick to one's own 'tribe' (a word Friel uses in both Translations and Making History), then the challenge of these plays would be diminished. But what makes these texts more significant and radical is that Friel goes beyond what would be an easily recognisable motif in order to present a far more difficult idea. For what the references to the mingling of blood, stock, mongrelism, seeds, cross-fertilisation and poisoning of the blood invoke is what Renaissance colonial theorists such as Edmund Spenser called 'degeneration' and what nineteenth century 'race' theorists were later to term 'miscegenation'. ${ }^{18}$ Although the word 'miscegenation' was coined in an anonymously published hoax pamphlet circulated in 1863 (which implied that the American Republican party favoured mixed-'race' relationships), the colonists in Ireland had long been concerned about the cultural and political dangers which followed the mixing of blood between the English and the Irish in marriage. Spenser for example warned specifically that 'these evill customes of fostering and marrying with the Irish [are] most carefully to be restrayned' because they caused English colonists 'so much to degenerate from their first natures as to grow wild'. ${ }^{19}$ The first use of the word 'hybrid' when born, sir, and a hybride'.

18. The claim here is not that 'degeneration' and 'miscegenation' are the 'same', but they are related concepts which function discursively in similar ways in very different contexts.

19. Edmund Spenser, A View of the State of Ireland (1596), in Sir James Ware, ed., The Historie of Ireland Collected by Three Learned Authors, Dublin, 1633, 48, 44. For a consideration of fears of cultural 'degeneration' amongst the colonists in late sixteenth century Ireland, including a discussion of Edmund Spenser's role in the propagation of such beliefs, see Crowley, Wars of Words: The Politics of Language in Ireland 1537-1922, chapter 2, 'Reforming the Word and the words of the Irish, 1537-1607’.
It would be plausible to argue that Translations and Making History simply reflect the bitterness and despair of the context in which they were written. Yet in the end such a reading would reduce these texts to reflexes of history and thus to miss the disturbing challenge of Friel's stagecraft. For the contention of this essay has been that Friel's work refuses the idea that drama can be read off against history in any simple way precisely because his plays raise wider issues about historical representation. That is not to say that these works reject the criteria of truth and falsity, since the point of the ironic use of the motifs of degeneration and miscegenation is to pressure the audience to reflect on the general applicability of those criteria and on the costs of jettisoning them. If such a strategy works and there is no guarantee that it will - one implicit question that the audience might be brought to address then is not so much why O'Neill's wife dies, but why anyone assumes that it is her marriage that caused the poisoning of her blood. Another might be why, in a context of colonial war, anyone might think that the reasons for the tragic failure of crosscultural exchange are biological rather than historical. Thus rather than leading an audience to conclude that particular versions of history are either true or false in any simple way (a game played by some nationalist and revisionist historians of colonialism in Ireland over the past twenty years or so), the achievement of Friel's work is to have the effect of making us think about the ways in which the past is represented and the functions and uses which it serves in the present. ${ }^{20}$ That is not to duck the Archbishop's question - 'are truth and falsity the proper criteria?' - after all the stories of degeneration and miscegenation are untrue in fact - and we need to insist upon that for very important political and ethical reasons. But like the claims about degeneration and miscegenation, assertions of truth or falsity in historical representation are open to question and verification according - precisely - to criteria. The argument will then of course shift to the criteria themselves, but the internal, logical link is necessary and significant.

20. For an account of such debates in and around Irish historiography, see D.G.Boyce and Alan O'Day, The Making of Modern Irish History: Revisionism and the Revisionist Controversy, London: Routledge, 1996. 
Since the cessation of organised, large-scale, institutional violence on the island of Ireland in 1996, the debates surrounding historical representation have not gone away; indeed in one sense they have intensified. When the conflict was at its height, many of the versions of the past that were propagated - ranging from the official accounts of the British and Irish States to those depicted in Republican and Loyalist murals - could be understood as simply expressing the interest of those who had authored them. Though they were in themselves often more complicated than they appeared, it was at least one of the benefits of such forms of representation that they could be decoded relatively easily. In post-conflict Ireland, however, particularly within Northern Ireland, the questions which Friel's plays raise have taken on new urgency. For in a society which has emerged - at least ostensibly - with a democratic settlement from a bitter postcolonial war, the issue of how to remember the past is now urgent and complex. Two examples may illustrate the point. First, there is the question of the future site of the Maze Prison, the jail used to incarcerate many of the Republican and Loyalist paramilitary prisoners convicted of violent offences during the Troubles. For Irish Republicans in particular this place is historically extremely significant; it was here that ten Republican prisoners died on hunger-strike protesting their treatment as criminals rather than political prisoners by the British State and it was on the basis of that struggle that the Republican movement as a political, rather than simply military, organisation was launched. Current proposals for the location include a museum, a conflict transformation centre, an office, hotel and leisure complex, and a sports stadium. How would each of these possible uses serve as a way of dealing with the past? Would the preservation of the site as a museum satisfy the demands of those who lay claim to it as the locale of a never-to-be-forgotten act of sacrifice? If it became a conflict transformation centre, could it become useful as a way of negotiating between the past and the present as a way of opening up a different future? Would the building of a sports stadium be a way of simply negating the past through the constantly renewed but ephemeral nature of the events staged there? The second example is the fate of the street murals mentioned earlier in the essay which were painted during the Troubles or which have appeared since the end of the violence. Many if not most of the murals have already disappeared - replaced by others proclaiming new messages, faded with the ravages of time and Ulster weather, whitewashed in order to eradicate messages deemed no longer suitable by local communities or the organisations which commissioned and sponsored them.

But are any of the older murals - some of which were representations that glorified atrocious violence on both sides of the sectarian divide - to be preserved on site as uncomfortable and enduring testaments to the complicated and bitter past? ${ }^{21}$ Or are they to be packaged and commodified, as many of them have been, for the now well-established Troubles tourism industry? ${ }^{22}$ In what ways, in short, will the past be dealt with?

How are such questions to be answered? Who will be allowed to answer them? What is at stake in the answers? One thing is clear: however these questions are addressed, issues of history and memory will undoubtedly play an important role in the deliberations. Whether truth and falsity are amongst the proper criteria by which the judgments will be made remains to be seen.

21. It would be possible to trace a historical trajectory to the Troubles by 'reading' the murals. In general, for example, in the CCDL collection cited above in note 5 , it is possible to discern a clear shift from the particularities and generalities of violent struggle in the early Republican murals to a concern with democratic politics and legal and cultural issues in the later paintings.

22. Many of the remaining murals have evidently been designed to deliver an 'acceptable' version of history - past and present - to the consumers of such images. It is possible that now, as throughout the period of conflict, graffiti offers an insight into the difficulties, desires, realities and humour of at least one section of the population (graffiti is cheap and difficult to police). One of the most interesting and neglected aspects of the murals during the height of the Troubles was the extent to which certain images were graffitied and those which were not. Not many escaped - a fact which perhaps illustrates the specific though often implicit tensions which existed between political organisations such as Sinn Féin and the local youth population in particular areas. 


\section{Works Cited}

Anderson, Christopher. 1818. Brief Sketch of Various Attempts which Have Been Made to Diffuse a Knowledge of the Holy Scriptures through the Medium of the Irish Language. Dublin.

The Bible. Authorized King James Version. 1997. Oxford: Oxford University Press.

Boyce, D.G. and Alan O’Day. 1996. The Making of Modern Irish History: Revisionism and the Revisionist Controversy, London: Routledge.

Canny, Nicholas. 1982. 'The Formation of the Irish Mind: Religion, Politics and Gaelic Irish Literature 15801750', Past and Present, 95, 91-116.

Clark, Elizabeth A. 2004. History, Theory, Text: Historians and the Linguistic Turn, Cambridge, Mass., Harvard University Press.

Conflict Archive on the Internet (CAIN). n.d. http://cain.ulst.ac.uk/

Crowley, Tony. 2005. Wars of Words: The Politics of Language in Ireland 1537-1922, Oxford: Oxford University Press. . 2007. 'Murals of Northern Ireland', Claremont Colleges Digital Library. http://ccdl.libraries.claremont.edu/col/mni/

De Saussure, Ferdinand. 1981 (1916). Course in General Linguistics, trans. and annotated by Roy Harris, London: Duckworth.

Friel, Brian. 1981. Translations , London: Faber and Faber. . 1989. Making History, London: Faber and Faber.

Jameson, Frederick. 1984. 'Postmodernism, or, the Cultural Logic of Late Capitalism', New Left Review, I/146, 53-92.

Richtarik, Marilynn. 1994. Acting Between the Lines: The Field Day Theatre Company and Irish Cultural Politics 1980-1984, Oxford: Clarendon Press.

Spenser, Edmund. 1633 (1596). A View of the State of Ireland, in Sir James Ware, ed., The Historie of Ireland Collected by Three Learned Authors, Dublin.

White, Hayden. 1987. The Content of the Form: Narrative Discourse and Historical Representation. Baltimore: The Johns Hopkins University Press. 